\title{
Sustainable Analysis in Ecology Dimension of Dairy Cattle for Development of Livestock Area in Batu City Indonesia
}

\author{
Rini Mastuti ${ }^{1}$, Zaenal Fanani ${ }^{2}$, Bambang Ali Nugroho ${ }^{2}$, Hari Dwi Utami ${ }^{2}$ \\ ${ }^{I}$ Student of Doctorate Program in Animal Husbandry Faculty, University of Brawijaya, Indonesia \\ ${ }^{2}$ Lecturer of Doctorate Program in Animal Husbandry Faculty, University of Brawijaya, Indonesia
}

\begin{abstract}
This study carry the objective to analyze index value and sustainable status of dairy cattle in Batu city for its ecological dimension. Analysis method used is Multi Dimensional Scaling (MDS) known as Rap-USPE. Analysis result is sustainable index value for ecology dimension with 59,02 percent or categorized into quite sustainable. Leverage analysis result showed two sensitive attributes contributing toward improvement of sustainable index value which is availability of greens woof and waste management.
\end{abstract}

Keywords: sustainability, Rap-USPE, dairy cattle, greens, waste

\section{Introduction}

Currently, fresh milk production in Indonesia has been produce by local dairy cattle with business scale 1-3 dairy cattle per farmer. Local milk production has supply no more than 25 percent of national demand, the remain of 75 percent came from import. Higher imported milk has brought loss either for dairy cattle business or the government since it would deplete national exchange, causing loss of revenue potential that should be gain by government from tax, also causing opportunity loss from neglected potential resources available for development of dairy product agribusiness (Kementan, 2013). Dependency toward imported milk has encourage the government to conduct several efforts to develop dairy business in areas contributing toward national dairy product in the hope to being able in becoming self-sufficient to meet domestic dairy demand. Government has declare Indonesia is supporting dairy product in 2025 which means that milk demand for industrial need can be met self-sufficiently. In this program, government has targeting that fresh milk production should reach 5,371 million tons/year with milk productivity 19,67 litre/cattle/day and milk consumption level of society should attain 30 litre/people/year (Ditjen PPHP, 2014).

To attain this target, one of the government program is by establishing National Cattle Areas for development of dairy cattle through Kementan RI No: 43/Kpts/PD410/1/2015. Batu city is one of the six areas for dairy cattle development in Indonesia for the next five years in supporting self-sufficient national dairy product. Dairy cattle development program is expected to be sustainable in attaining target also maintain self sufficiency of national dairy milk. Regarding this, sustainable status should be reviewed for dairy cattle in Batu city related with its ecological dimension as area for dairy cattle development. Result of this study can be used for consideration by policy maker particularly in Batu city government and stakeholders in developing sustainable dairy cattle business in Batu city.

This study has the objectives to analyze index valud and sustainable status of dairy cattle business in Batu city regarding its ecological dimension. Analysis method used is Multi Dimensional Scaling (MDS) known as Rap-USPE. Analysis result is expressed in sustainable index value also sustainable status in dairy cattle business regarding its ecological dimension. Analysis result would facilitate the government or stakeholder in composing and implementing program also conducting improvement toward sensitive attributes which contributing toward sustainable status of dairy cattle in its ecological dimension to attain success in development of sustainable dairy program.

\section{Framework Study Method}

\section{Material And Methods}

Government has established cattle area development in Batu city in order to develop sus tainable dairy cattle business in supporting self sufficient national milk production. In developing dairy business, there should be sustainable development concept and it should be seen in whole within agribusiness system conception from upstream to downstream (Saragih, 2000) as the form of responsibility of today's generation for future generation other than to maintain self sufficient dairy program to keep operating. According to Ditjenak (2009), development in cattle farming can be said sustainable if it use sustainable development concept. According to Mersyah (2005), reference criterion for sustainable development in 
its principle would related with ecology, economy, social-cultural, legal-institutional and technology dimensions.

Dairy business can be said fulfilling ecological dimension in its sustainable development if this business is in accord with condition and environmental support capacity, did not conduct excessive exploitation toward natural resources, did not conduct overly waste discharge related with environment support capacity thus creating pollution and implementing environmental preservation management. According to Irwan (2014), to attain sustainable life, people should learn how to understand its environment and be smart in using natural resources in accountable manner for safety and preservation reason. Therefore, attributes used to reflect ecological dimension in this study is area altitude, usage of chemical fertilizer, water sources, infrastructure condition, air temperature, availability of green woof and others.

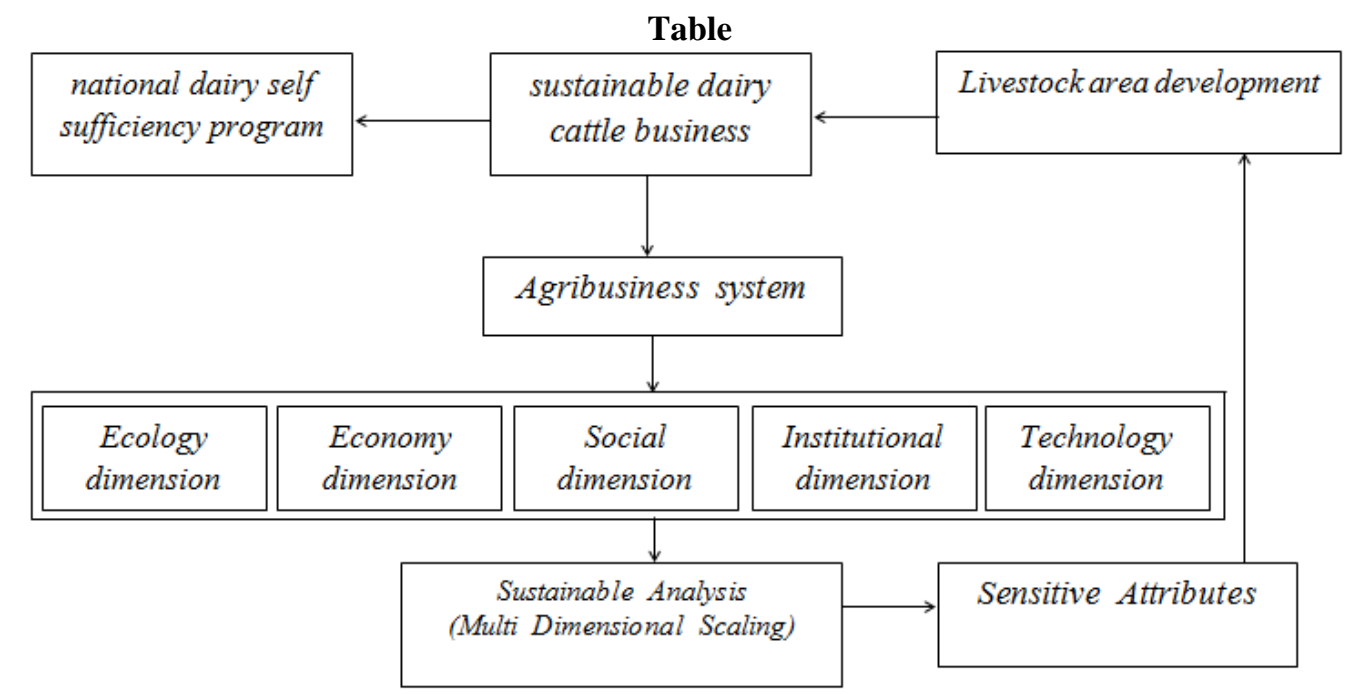

Figure1. Study framework for Sustainable Analysis of Dairy Cattle Business in Batu city for Cattle Area Development.

\section{Time and Place of Study}

Study site lies in Batu city, East Java Province. Study site determination was done in purposive manner with consideration that: (1) Dairy cattle business as the superior cattle business in Batu city, (2) Batu city as fresh milk supplier for milk processing industry, and (3) Batu city has been appointed as one of national dairy cattle development area. This study particularly done in Tlekung village in Kecamatan Junrejo, Oro-Oro Ombo and Pesanggrahan village in Kecamatan Batu and Gunungsari village in Kecamatan Bumiaji, which are dairy cattle development areas based on RTRW Batu city of 2010-2030. This study was conducted in January-June 2015.

\section{Data Type and Sources}

Data used in this study is primary and secondary data. Primary data obtained from opinion of 30 key person while secondary data obtained from literature review, internet browsing and supporting documents from several institution related with the study. Key person was chosen due to several consideration, as follows: a) Having reputation, position/title in its competence regarding this subject, b) Having experience and competence in accord with this subject, c) Have the commitment regarding with this matter, d) Neutral and willing to accept opinion from other respondent, e) Willing to be asked of opinion and be at study site. Type of study data or ecology dimension attributes was given in Supplement1.

\section{Data Collection Method}

Data collection in dairy business ecology sustainable analysis at Batu city for cattle area development was done through field survey method, questionnaire, interview, and discussion with related respondents regarding study topic. 


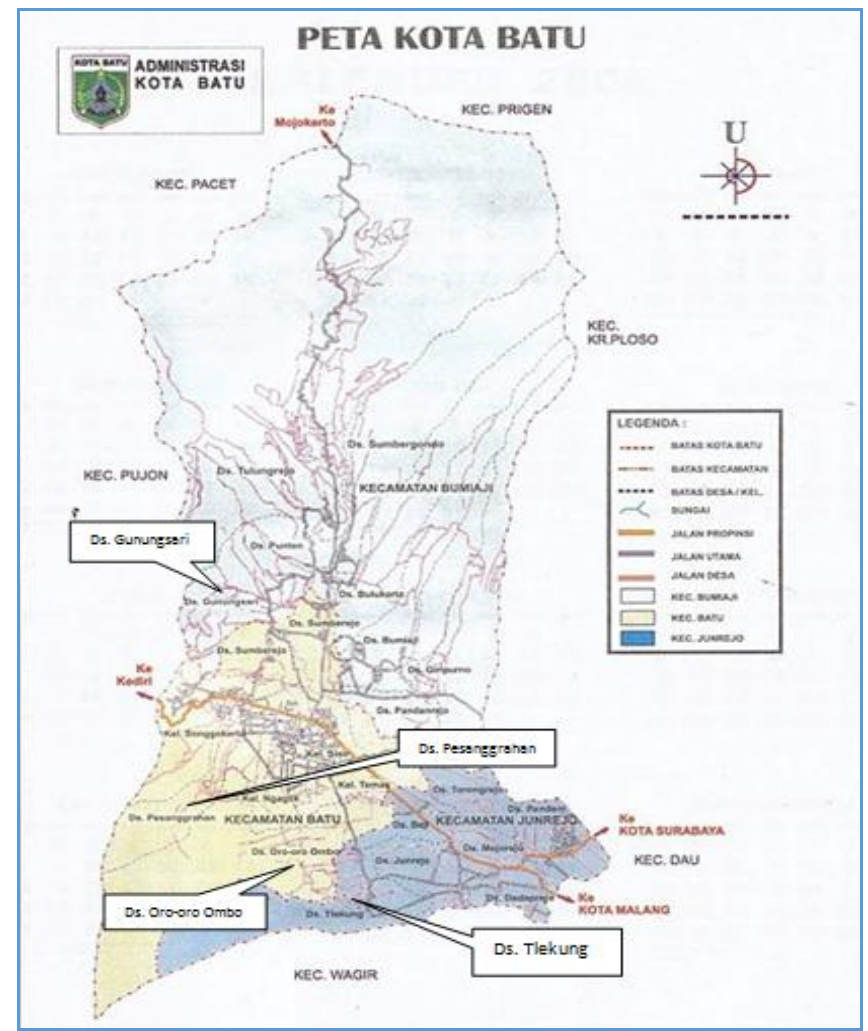

Figure2. Location Map of Study Site in Batu city

\section{Analysis Method}

Sustainable analysis method of dairy business in ecological dimension at Batu city for cattle area development is using Multi Dimensional Scaling (MDS) approach known as Rap-USPE (Rapid Appraisal for Dairy Cattle Business). Rap-USPE is adopting analysis technique of Rapfish (Rapid Appraisal for Fisheries) developed by Fisheries Center, University of British Columbia (Fauzi and Anna, 2005). MDS method is a statistical analysis technique which transforming each dimension and multidimensional in sustainability dimension of dairy cattle business. In this study, there are 10 attributes used to value sustainable status of dairy business in its ecological dimen sion.

Index determination method and sustainable status of dairy cattle business was using RapUSPE. Index and sustainable status determination is based on stages: 1) Reviewing attributes in each sustainable dimension and assessed those attributes based on actual data through field observation, indepth interview with key person and literature review, 2) Attributes score values of each sustainable dimension would then analyzed in Rapfish program with Microsoft Excel thus attained a value known as its sustainable index, 3) Categorizing this sustainable index value based on sustainability interval to obtain sustainability status. Sustainability score values interval for each dimension are: poor $(0-25)$, lack/not quite enough (26-50), enough/mediocre (51-75) and good (76-100).

Position of sustainable point can be shown in vertical line or horizontal line. Sustainability index value lies in 0 percent (poor) until 100 percent (good). If dimension assessed with its index value lies under 50 percent, thus it is considered to be less or unsustainable, and if dimension assessed is above 50 percent, thus this dimension can be said as sustainable. This assessment is illustrated in figure 3.

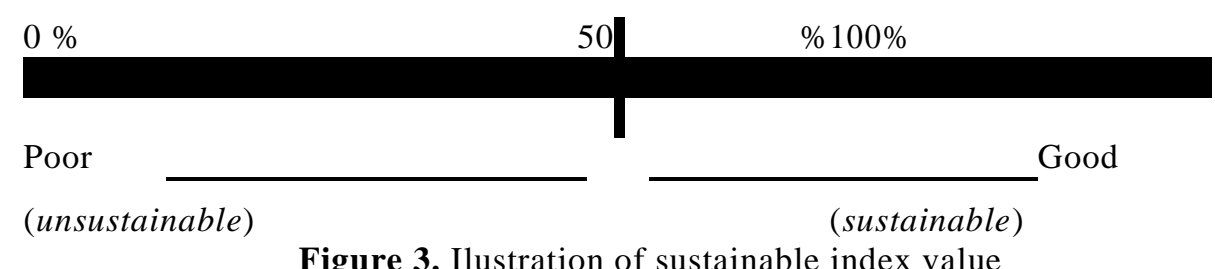

Source: Compiled by authors, 2014 
In analysis, Rap-USPE is used but it also conduct Monte Carlo simulation, leverage analysis, determination coefficient $\left(\mathrm{R}^{2}\right)$ analysis and stress value determination. Monte Carlo simulation was used to suspect effect of error toward confidence interval 95\%. Leverage analysis was used to look for sensitive attributes affecting sustainable status by seeing its priority order in leverage analysis result by looking at RMS (Root Mean Square) value increment in x axis. Whereas larger RMS value means larger attributes role in improving sustainable status of dairy cattle business. Sustainable index value of Monte Carlo analysis result and MDS analysis result would be compare to each other, if increment is small or under $25 \%$ then it indicated that: 1) Repeating analysis processes is stable, 2) Data entry error and lost data can be avoided, 3) Error in score determination of each attributes is relatively small, 4) Score determination variation due to opinion difference is relatively small, which means that Rap-USPE method is good enough to be used as a tool to evaluate sustainability of dairy cattle business in Batu city and this result is almost real and those mapped data has been analyzed in good manner.

Stress value is lack of fit measure, whereas higher stress value would be more unfit. Stress value is used to see whether output result is approaching the real condition or not. Closer to zero means that output produced is more like the real condition. Determination coefficient $\left(\mathrm{R}^{2}\right)$ value is used to found out the proximity between data and perceptual map. Through $\mathrm{R}^{2}$ we can conclude whether data we own can be adequately mapped or not. $\mathrm{R}^{2}$ value closer to 1 means that data is almost perfectly mapped. Perfect model in MDS is shown with $\mathrm{R}^{2}$ value $=1$.

Ordinance technique (distance determination) within MDS is based on Euclidian Distance in $n$ dimension space, with equation as follow:

$d=\sqrt{\left(\left|X_{1}-X_{2}\right|^{2}+\left|Y_{1}-Y_{2}\right|^{2}+\left|Z_{1}-Z_{2}\right|^{2}+\ldots\right)}$

Configuration or ordinance from an object or point in MDS then would be approximated by regressing Euclidian distance $\left(d_{i j}\right)$ from I to $\mathrm{j}$ with initial point $\left(\delta_{i j}\right)$ as equation below:

$$
d_{i j}=\alpha+\beta \delta_{i j}+\varepsilon
$$

Generally, there are three technique used to regressed the above equation, which is least square method (KRYST), alternate least square based on root of Euclidian Distance (squared distance) or known as ALSCAL method. ALSCAL algorithm is the most appropriate method for Rapfish and easily available in almost all statistical software (SPSS and SAS). ALSCAL method optimize square distance ( squared distance $=d_{i j k}$ ) toward square data (initial point $=o_{i j k}$ ), in three dimension $(\mathrm{i}, \mathrm{j}, \mathrm{k})$ is written in a formula called $S$-Stress as follow:

$$
S=\sqrt{\frac{1}{m} \sum_{k=1}^{m}\left[\frac{\sum_{i} \sum_{j}\left(d_{i j k}^{2}-o_{i j k}^{2}\right)^{2}}{\sum_{i} \sum_{j} o_{i j k}^{2}}\right]}
$$

Whereas square distance is weighted Euclidian distance, or written as:

$$
d_{i j k}^{2}=\sum_{a=1}^{r} w_{k a}\left(X_{i a}-X_{j a}\right)^{2}
$$


Simple MDS analysis stage is given in figure 4.

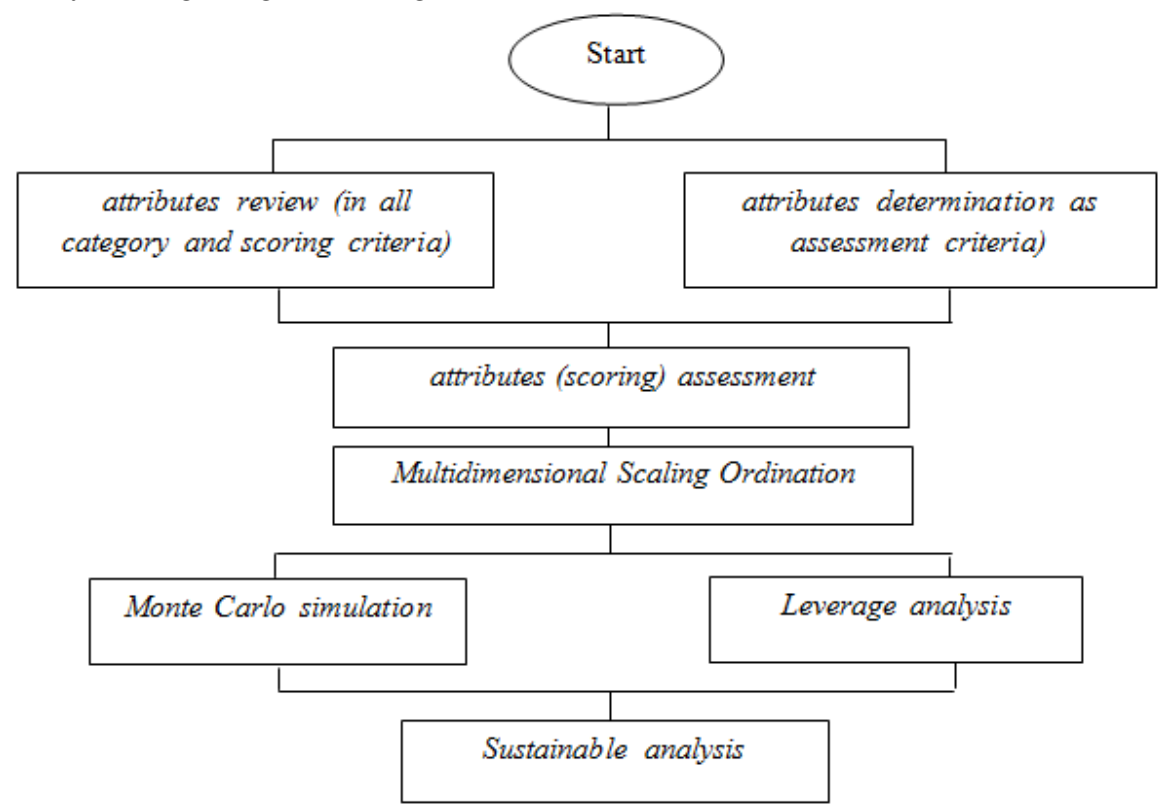

Figure 4. Rapfish Application Process

Source: Alder et al. (2009) in Fauzi \& Anna (2005)]

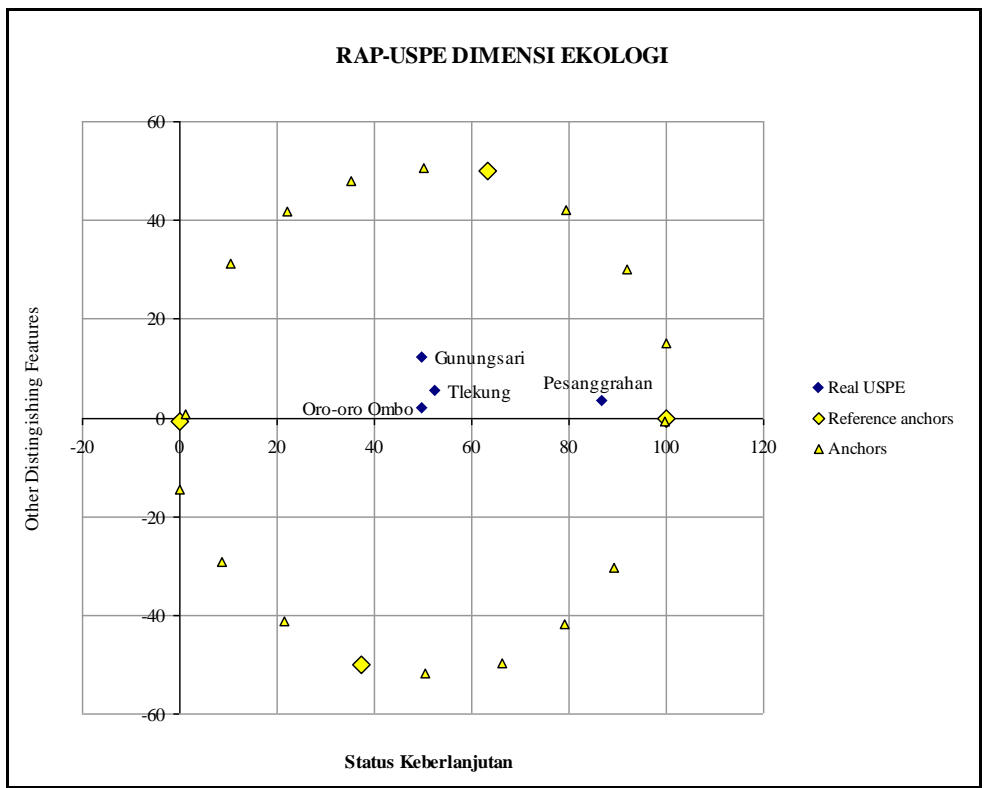

Figure 5. Sustainable index value diagram of ecological dimension of dairy cattle business in Batu city.

\section{III.Result And Discussion}

Analyzed attributes in sustainable ecology dimension of dairy business are: (1) area altitude, (2) usage of chemical fertilizer, (3) water source, (4) infrastructure condition, (5) air temperature, (6) availability of greens woof, (7) usage of farm waste as livestock feed, (8) manure management, (9) biogas availability, and (10) land slope. Analysis result of Rap-USPE in ecology dimension of dairy cattle business in Batu city for livestock area development has resulted sustainable index value of $59,02 \%$ and based on sustainable status classification it categorized in quite sustainable. While for sustainable index value and status of ecology dimension in each village are: Tlekung village with $52,64 \%$ (quite sustainable), Oro-Oro Ombo village with $49,86 \%$ (less sustainable), Pesanggrahan village with $83,86 \%$ (very sustainable) and Gunungsari village with $49,72 \%$ (less sustainable) as seen in Figure 5. Pesanggrahan village has the highest sustainable index value in ecology dimension due to its higher score in ecology dimension attributes compared to those of Tlekung, Oro-Oro Ombo and Gunungsari village. Pesanggrahan village located in highest altitude compare to other villages. This areal altitude 
has related with air temperature and fresh milk production whereas higher altitude would bring colder air temperature and more supporting optimum fresh milk production since dairy cattle originally came from subtropical or temperate region with colder air temperature. Farmer would commonly used organic fertilizer from biogas usage waste to increase land fertility. Water source in Pesanggrahan village is quite abundant, with very good infrastructure condition particularly access for fresh milk collection transportation. Biogas installation has been built to collect and processing manure into electrical energy and organic fertilizer thus decreasing environmental pollution, giving more added value for dairy business, maintain and improving land fertility. Farmer also maintain and increase green area by planting grass in pine tree canopy to preserve livestock greens feed thus grass supply to meet the need of dairy cattle in Pesanggrahan village is relatively stable and abundant even in dry season.

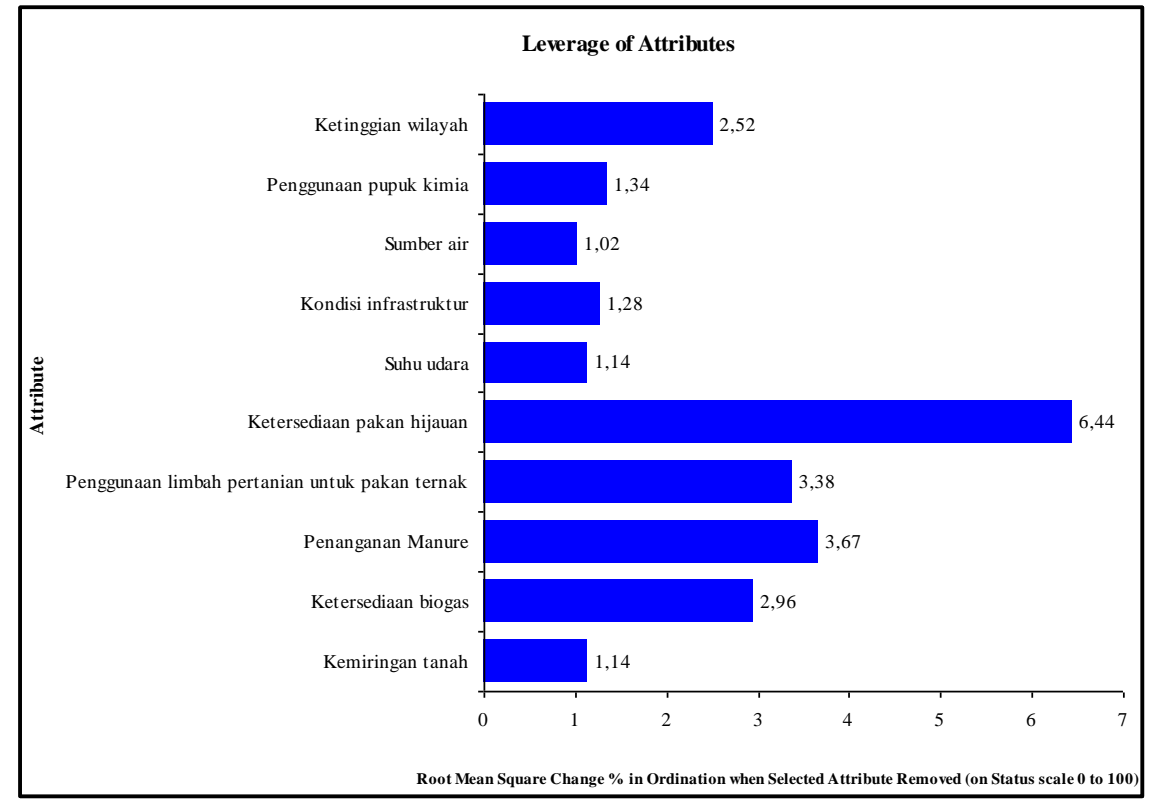

Figure 6. Leverage analysis result diagram of ecology dimension attributes of dairy cattle business

Based on leverage analysis result in figure 6 , there are three sensitive attributes affecting sustainable index value of ecology dimension of dairy cattle business, which are, availability of green feed and manure management. The existence of both attributes has affecting sustainability of dairy cattle business, such as 1) Availability dan continuity in green feed with good quality and quantity would assured green feed supply for livestock. Green feed supply has become an important issue since farming area in Batu city has greatly reduced due to changing function in land utilization toward non farming land for residential and tourism purposes along with development of Batu city as Tourism city. This has greatly affecting farmer's ability to supply greens feed for livestock. Easily collected grass has become more limited in its availability therefore farmer would necessary to give more effort in looking for grass in far places. In dry season, it is harder for farmer to attain fresh grass, and they sometimes need to buy grass from out of the city. This condition has greatly decrease farmer's interest to continue their business, thus lots of farmer decided to close their dairy cattle business and choose to involved in hospitality sector. Intervention should be done by related government, cooperatives or farmer himself to secure the land either for stable or greens area which has become more threatening toward the existence of dairy cattle business in Batu city; 2) Manure management is highly important to maintain environment without pollution. With proper treatment, manure can be use as organic fertilizer to improve land fertility thus it would help in maintaining green feed supply availability. Manure dumped into environment, if it is over than its collection capacity to naturally decompose it, would pollute the land, air and water environment. With continued pollution, it would decrease environment's support capacity regarding dairy catlle business sustainability. Therefore, we need to find a solution and cooperation from all stakeholder to actively involved in handling, processing and utilizing manure and make it into biogas or organic fertilizer so that manure would no longer pollute the surrounding environment and also create added value toward dairy cattle business.

Monte Carlo analysis result showed that sustainability index value of ecology dimension of dairy cattle business in Batu city for livestock area development in confidence interval 95\%, has 
showed no significant different with Rap-USPE (Multidimensional Scaling = MDS) analysis result. This means that error in data input and lost data can be avoided, error in analysis and scores determination is relative small, score determination variation that occur due to opinion difference of keypersons is relatively small and data analysis conducted repeatedly is quite stable. Difference in sustainability index value of economy dimension in MDS and Monte Carlo is showed in Table 1.

Table 1. Difference in sustainability index value of Rap-USPE and Monte Carlo

\begin{tabular}{|l|r|l|l|}
\hline \multirow{2}{*}{ Dimension } & \multicolumn{2}{|c|}{ Sustainability Index Value (\%) } & \multirow{2}{*}{ Difference } \\
\cline { 2 - 4 } & Rap-USPE & Monte Carlo & $\mathbf{0 , 1 3}$ \\
Ecology & $\mathbf{5 9 , 0 2}$ & $\mathbf{5 8 , 8 9}$ & 0,18 \\
Tlekung village & 52,64 & 52,46 & 0,09 \\
Oro-oro Ombo village & 49,86 & 49,77 & 0,16 \\
Pesanggrahan village & 83,86 & 83,70 & 0,08 \\
Gunungsari village & 49,72 & 49,64 & \\
\hline
\end{tabular}

Analysis result of Rap-USPE showed that all reviewed attributes in ecology dimension of dairy cattle business in Batu city for livestock area development is quite accurate. This can be seen in Table 2 whereas MDS analysis result showed stress value for all dimension is less than 0,25 while RSQ is almost approaching 1 which means that statistical test result showed that Rap-USPE method is proper enough to be used as tool to evaluate sustainability of dairy cattle business in Batu city and this result is approaching the real condition also analyzed data has been appropriately mapped.

Stress is a lack of fit measure, higher stress value would means more unfit. Stress value is used to see whether output result is approaching the real condition or not. More approaching zero, resulting output would approaching the real condition on the field. $\mathrm{R}^{2}$ value is used to found out approximity between data and perceptual map. Through $\mathrm{R}^{2}$ we could conclude whether data we own can be better mapped or not. This is in accord with Kavanagh (2001) opinion, where he suggest that analysis result is quite appropriate if stress value is smaller than 0,25 (0,25 percent) and determination coefficient value $\left(\mathrm{R}^{2}\right)$ is approaching 1 which means that data is more perfectly mapped.

Table 2. Analysis result of Rap-USPE for stress value and $\mathrm{R}^{2}$

\begin{tabular}{|c|c|}
\hline Description & Ecology \\
\hline Stress & 0,1590 \\
\hline $\mathrm{R}^{2}$ & 0,9194 \\
\hline Number of Iterations & 3 \\
\hline
\end{tabular}

\section{Conclusion}

\section{Conclusion And Suggestion}

Based on analysis result of Rap-USPE, ecology dimension of dairy cattle business in Batu city for livestock area development is in sustainable condition, while for Tlekung village is quite sustainable, Oro-Oro Ombo village is less sustainable, Pesanggrahan village is very sustainable, and Gunungsari is less sustainable. Sensitive ecology dimension attributes are green feed availability, manure management and farm waste usage for livestock feed.

\section{Suggestion}

Suggestion in this study are there should be better management and improvement regarding sensitive attributes of ecology dimension in improving sustainability index value of ecology dimension of dairy cattle business in Batu city for livestock area development.

\section{References}

[1]. Irwan, Zoer'aini D., 2014. Prinsip-Prinsip Ekologi. Ekosistem, Lingkungan dan Pelestariannya. PT. Bumi Aksara. Jakarta.

[2]. Kavanagh, P. (2001). Rapid Appraisal of Fisheries (Rapfish) Project. Rapfish Software description (for microsoft excel). University of British, Fisheries Centre, Vancouver.

[3]. Saragih, Bungaran. 2001. Pembangunan Sistem Agribisnis di Indonesia dan Peranan Public Relation. Makalah. Seminar "Peranan Public Relation dalam Pembangunan Pertanian", tanggal 19 April. Bogor: Program Pascasarjana PS. KMP, Institut Pertanian Bogor.

[4]. Direktorat Jenderal Peternakan. 2009. Rencana Strategis Direktorat Jenderal Peternakan Tahun 2010-2014. Jakarta: Direktorat Jenderal Peternakan Departemen Pertanian Republik Indonesia.

[5]. Mersyah, Rohidin. (2005). Desain Sistem Budidaya Sapi Potong Berkelanjutan untukMendukung Pelaksanaan Otonomi Daerah di Kabupaten Bengkulu Selatan.Disertasi, IPB.

[6]. Fauzi, Akhmad dan Suzy Anna. (2005). Permodelan Sumberdaya Perikanan dan Lautanuntuk Analisis Kebijakan. PT. Gramedia Pustaka Utama, Jakarta. 